the British Broadcasting Corporation, in the series now well known as "Science Survey". This series has proved to be a remarkable achievement. Sir Edward Appleton said at the British Association meeting at Liverpool in 1953 that: "You have not really got to the bottom of the matter yourself if you cannot explain it to the man in the street"; Dr. Clow has always seemed to bear this in mind when selecting his speakers for Science Survey. Nevertheless, he has also always insisted on substance in these broadcasts and an absence of "talking. down' to the listener. Scientific material, even that of immediate human or sociological or industrial importance, is sometimes very difficult material when being prepared for interpretation to the nonscientist, either by radio or through the newspaper press, yet it is possible to hold the interest of a listener or reader once his interest is captured at the initial stages. But this needs careful preparation and handling, and it seems that here Dr. Clow has revealed a genius for production. It is good, therefore, to have the opportunity on this 250 th anniversary to congratulate Dr. Clow on his excellent work in scientific exposition and interpretation through the medium of the radio.

\section{Science and Foreign Relations in the United States}

WHILE the symposium of papers contributed to the September issue of the Annals of the American Academy of Political and Social Science gives a clear factual account of the part that the United States Congress plays in the foreign relations of the United States, it will disappoint those whose hopes had been raised by the appearance of the Berkener report on "Science and Foreign Policy". Following some account of the constitutional position of Congress and of the part it has played before and after 1900, the functions of Congress in foreign relations are explained and then the relations between legislature and executive. Nowhere, however, not even in the concluding discussion of the future of Congress in foreign relations, is any reference made to the recommendations of the Berkener report, and it would seem prudent to conclude that the likelihood of these recommendations being implemented is slight. The influence which science exerts on the foreign policy of the United States in the foreseeable future is likely to be negligible, at any rate until the public discussion of nuclear energy problems considered by Dr. J. B. Conant as desirable is also possible.

\section{Insect Enemies of Western Forests of the United} States

A FIELD manual by F. P. Keen on "Insect Enemies of Western Forests" has been issued as a revised edition by the United States Department of Agriculture (Misc. Pub. No. 273 ; pp. 280 ; Govt. Printing Office, Washington, D.C., $1952 ; 1$ dollar). It is a very practical illustrated manual covering a wide range of forest insect pests, and written for the use of forest rangers, field-men and others responsible for the protection of the forest resources of the United States. The raison d'etre is to bring together in summary form published bulletins, articles and records and also unpublished reports. The manual is restricted to insects found in forests west of the Great Plains, roughly the 100th meridian. In dealing with the control of the important bark beetles, of which some details of costs are given, the author correctly says: "At the best, remedial bark-beetle control is only a temporary expedient or a method of suppressing outbreaks that have been brought about through some interruption or disturbance of the biological balance". The only permanent protection to forests is by the maintenance of the natural balance.

\section{Fossil Water-Ferns}

A NотE in the Transactions of the Suffolk Naturalists' Society (8, Pt. 2) describes the discovery of two genera of water-ferns, Azolla and Salvinia, in interglacial deposits in Suffolk. Both these genera are new to the British Pleistocene flora, but have been found in interglacial deposits on the Continent. Azolla was found in the deposits at the classic site of Hoxne, and Salvinia in the interglacial deposit at Bobbitt's Hole, near Ipswich. Only the male and female spores of the plants have been found so far. The spores of the fossil Azolla are very similar to those of the modern A. filiculoides Lam., a species which was introduced into Britain towards the end of the nineteenth century. The species of fossil Salvinia has not yet been determined. (See also p. 187 of this issue.)

\section{Potassium Absorption by Growing Root Cells}

Usrog a technique, which is described, R. Brown and P. M. Cartwright (J.Exp. Bot., 4, 11, 195 ; 1953) have shown that when thin serial sections of maize root, taken from the apex backwards, are immersed in $\mathbf{0 . 0 1} \mathrm{N}$ solution of potassium chloride in water and in 2 per cent fructose, absorption of potassium by the distal or tip section, which consists almost entirely of meristematic cells, is abnormally low. This is attributed to the absence of a tonoplast surrounding a central vacuole in the cells of this region. The data for potassium absorption are presented in various ways, but when they are reduced to a unit cell basis they show that, per cell, absorption increases as expansion occurs in the root. This is ascribed to an increasing protein content. It is shown that during cell growth in the root, the cytoplasm differentiates in such a way that absorption per unit protein increases. When sugar is provided, the rate of absorption is always stimulated, though the effect of it on final concentration varies with the extent to which the tissue grows. Although when the root is sectioned the rate of absorption is lowest in the meristem, nevertheless this is the region of highest potassium concentration in the intact root. The mechanisms which may be involved in the different circumstances are discussed.

\section{The Flamanville Granite in Normandy}

IN 1894 Michel-Lévy published a memoir on the Flamanville Granite, long regarded as a classic, in which he recorded evidence indicating that the granite had been produced in situ from the preexisting rocks. Dr. N. R. Martin has recently carried out a structural study of the mass (Quart. $J$. Geol. Soc., 108, 311; 1953), using the techniques originated by the late Prof. Hans Cloos. Dr. Martin considers that the granite was emplaced as a diapir that forced its way through a belt of incompetent rocks-already folded on general east-west axeswhich were readily buckled still further and thrust aside. The directions of the primary flow-planes of the granite minerals and of the foliation of the surrounding hornfelses are said to be consistent with the conception that the granite was forcefully intruded through a 'neck' below what is now the eastern side of the mass. As the resulting pluton was 